\title{
Mitochondrial Effect of Orally Administered Dibutyl Phthalate in Rats
}

\author{
Kenji Murakami and Keitaro Nishiyama \\ Department of Hygiene, School of Medicine, The University of Tokushima, Tokushima \\ Tomihiko Higuti
}

Faculty of Pharmaceutical Sciences, The University of Tokushima, Tokushima

\section{INTRODUCTION}

Phthalate esters (PAEs) are used as plasticizers for polyvinyl chloride and widely distributed in our environment. Recently health hazards caused by PAEs have been reported ${ }^{1 \sim 3)}$.

Among the toxic effects of PAEs, mitochondrial effects have been studied by the following researchers. Lake et al. ${ }^{4 \sim 6)}$, Srivastava el $a .^{7}$ ), and Mann et al. ${ }^{8)}$ observed inhibited succinate dehydrogenase activity in liver homogenate from di-2-ethylhexyl phthalate (DEHP)-treated rats. Ohyama's showed in vitro that PAEs inhibited mitochondrial respiration, with di-n-butyl phthalte (DBP) showing the strongest effect, and he concluded that PAEs were inhibitors of electron and energy transfer systems but not uncouplers. Takahashi ${ }^{10)}$ also found inhibitory effects of PAEs on respiration in vitro and ascertained that PAEs acted mainly as energy-transfer inhibitors. Then, Inouye et al. ${ }^{11)}$ reported that PAEs acted in vitro as uncouplers rather than electron-transfer inhibitors.

Thus, these reports did not always coincide in terms of the site of action of PAEs on the mitochondrial respiration. In order to determine the inhibitory site of PAEs in mitochondrial respiration, we studied the effects of DBP on respiratory activity and dehydrogenases activities in rat liver mitochondria in vivo and in vitro.

\section{MATERIALS AND METHODS}

In vivo : Five male rats of the Wistar strain, about $320 \mathrm{~g}$ in weight were fed a powder diet containing 5\% DBP ad libitum. Pair feeding was also carried out in studying the dehydrogenase activity as described below. From the 35 th to 45 th experimental days, the rats were killed by decapitation and blood letting, and the liver, kidney, spleen and testicles were removed and weighed. Liver mitochondria were isolated by the Hogeboom method ${ }^{12)}$, and the protein content was determined by measuring the content of cytochrome $a+a_{3}$ using a Hitachi, Model 556, two-wavelength, double-beam spectrophotometer ${ }^{13,14)}$.

Respiratory activity was determined by the ordinal method ${ }^{15)}$ using a Yellow Spring, Model YSI53, oxymeter. The Medium A. $(4.5 \mathrm{~m} l)$ consisted of $5 \mathrm{mM} \mathrm{MgCl}_{2}, 2 \mathrm{mM}$ EDTA, $15 \mathrm{mM} \mathrm{KCl}, 50 \mathrm{mM}$ sucrose, $25 \mathrm{mM}$ Tris- $\mathrm{HCl}$ buffer ( $\mathrm{pH} 7.4$ ), and $20 \mathrm{mM} \mathrm{KH}_{2} \mathrm{PO}_{4}-\mathrm{K}_{2} \mathrm{HPO}_{4}$. As a substrate, succinate (with $2 \mu \mathrm{g}$ of rotenone), pyruvate (with $5 \mathrm{mM} \mathrm{L}$-malate) or glutamate (with $5 \mathrm{mM} \mathrm{L}$-malate), $10 \mathrm{mM}$ each was used. $\mathrm{ADP}$ and 2, 4-dinitrophenol (DNP) were used at concentrations of $250 \mu \mathrm{M}$ and $50 \mu \mathrm{M}$, respectively.

Dehydrogenase activity for each of these substrates was determined by the amount of reduced potassium ferricyanide ${ }^{16)}$ as measured with wavelength pair of $450 \mathrm{~nm}$ minus $500 \mathrm{~nm}$ in a Hitachi, Model 556, two-wavelength, double beam spectrophotometer. The concentration of mitochondria used was $1 \mathrm{mg}$ protein per $\mathrm{m} l$ medium. The medium $(3.0 \mathrm{~m} l)$ used was the same as the Medium A except that $1 \mathrm{mM}$ $\mathrm{KCN}, 20 \mathrm{mM}$ potassium ferricyanide, and $40 \mu \mathrm{M}$ DNP were also added. The substrates used were the same as those in the respiration study.

In vitro: Using mitochondria from intact rat liver, the effects of DBP on respiratory and dehydrogenase activities were observed in vitro. The effect on ATP production was also observed using 
submitochondrial particles prepared by the Hansen and Smith method ${ }^{17)}$, as described previously ${ }^{18)}$. The submitochondrial particles used were at a concentration of $1 \mathrm{mg}$ protein per $\mathrm{m} l$ medium. The medium $(1.5 \mathrm{~m} l)$ used was the same as the Medium A except that $10 \mathrm{mM}$ glucose, $0.1 \mathrm{mg}$ hexokinase, and $20 \mathrm{mM}$ $\mathrm{Pi}$ containing about $10^{6} \mathrm{cpm}{ }^{32} \mathrm{Pi}$ were also added.

\section{RESULTS}

\section{General findings}

Food consumption by DBP-treated rats was less than that of the control during the first week, then it recovered to the control level. Body weight showed a depressed gain during the first week, followed by a plateau, measuring $65 \%$ of the control value on the 35 th day (Fig. 1). Organ weights are shown in Table 1. The liver and spleen of treated rats presented no significant change in absolute weight, but a significant increase in relative weight. On the other hand, the testicle presented marked atrophy, showing $40 \%$ of the control value in absolute weight and $60 \%$ of the control value in relative weight.

Respiratory activity in liver mitochondria

Table 2 shows the respiratory activities in DBP-treated rat liver mitochondria. As shown in this Table, state 4 respiration was not significantly inhibited. The state 3 respiration was significantly inhibited in the presence of succinate or pyruvate. The $\mathrm{P} / \mathrm{O}$ ratio, however, did not differ from that of the control. DNP-induced oxygen uptake was almost the same percent of the control value as that seen in state 3 .

The results obtained in vitro are shown in Table 3. At concentrations of 50 to $100 \mu \mathrm{M}$ DBP, inhibition of state 3 respiration was the same as that seen in vivo. State 4 respiration did not change at a concentration lower than $100 \mu \mathrm{M} \mathrm{DBP}$, but was weakly stimulated at a higher concentration. Respiratory control was completely lost at higher than $150 \mu \mathrm{M}$.

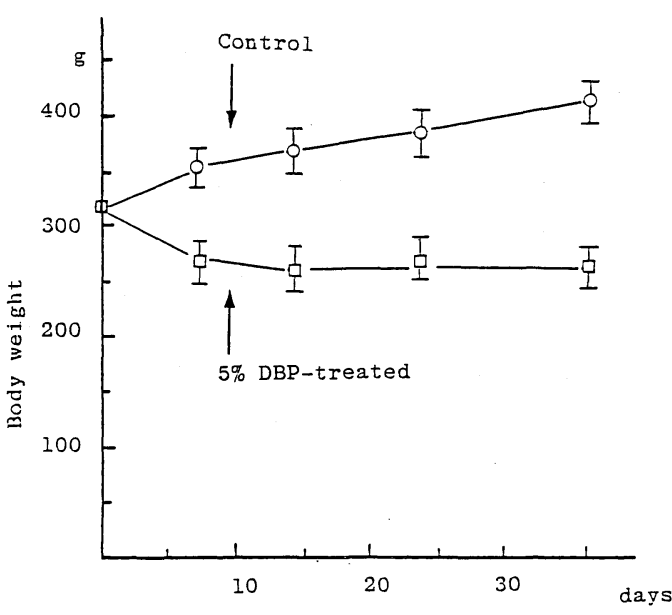

Fig. 1 Growth curves for normal and DBP-treated rats. Conditions were as described under the Materials and Methods. Vertical lines indicate S.E.

Table 1 Organ weight of DBP-treated rats. DBP was administered as described under the Materials and Methods.

\begin{tabular}{lccc}
\hline \multicolumn{1}{c}{ Organ } & Control & DBP-treated & \% of control \\
\hline Absolute weight $(\mathrm{g})$ & $16.4 \pm 2.1$ & & \\
Liver & $2.90 \pm 0.27$ & $17.9 \pm 1.7$ & 109.1 \\
Kidney & $0.72 \pm 0.15$ & $2.51 \pm 0.13$ & 86.6 \\
Spleen & $3.49 \pm 0.26$ & $0.83 \pm 0.19^{\mathrm{b}}$ & 115.2 \\
Testicle & $1.42 \pm 0.44^{\mathrm{a}}$ & 40.7 \\
Relative weight $(\mathrm{g} / 100 \mathrm{~g}$ of body weight) & & \\
Liver & $3.9 \pm 0.4$ & $6.8 \pm 0.8^{\mathrm{a}}$ & 174.3 \\
Kidney & $0.70 \pm 0.04$ & $0.95 \pm 0.07^{\mathrm{a}}$ & 135.7 \\
Spleen & $0.18 \pm 0.03$ & $0.32 \pm 0.09^{\mathrm{a}}$ & 177.8 \\
Testicle & $0.84 \pm 0.08$ & $0.54 \pm 0.18^{\mathrm{a}}$ & 64.3 \\
\hline
\end{tabular}

Each value represents the mean $\pm \mathrm{SE}$ of five animals. a, b : Significantly different from control $(\mathrm{a}: p<0.01$, $\mathrm{b}: p<0.05)$. 
Table 2 Respiratory activity in liver mitochondria of DBP-treated rats. Conditions were as described under the Materials and Methods. P: O ratios and respiratory control index ( $\mathrm{RCI}=$ State $3 /$ State 4$)$ were caluculated from the traces of oxygen uptake recorded according to the method of Hagihara ${ }^{26)}$.

\begin{tabular}{|c|c|c|c|c|c|}
\hline & \multicolumn{2}{|c|}{$\mathrm{O}_{2}$ uptake $^{\mathrm{a}}$} & \multirow[b]{2}{*}{$\mathrm{RCI}$} & \multirow[b]{2}{*}{$\mathrm{P}: \mathrm{O}$} & \multirow{2}{*}{$\frac{\mathrm{O}_{2} \text { uptake }^{\mathrm{a}}}{\mathrm{DNP} \text {-induced }}$} \\
\hline & State 4 & State 3 & & & \\
\hline \multicolumn{6}{|c|}{ Succinate as a substrate } \\
\hline Control & $17.1 \pm 3.7$ & $74.6 \pm 12.6$ & $4.4 \pm 0.7$ & $1.8 \pm 0.2$ & $89.5 \pm 10.4$ \\
\hline DBP-treated & $15.6 \pm 6.0$ & $47.7 \pm 12.3^{c}$ & $3.1 \pm 0.8^{c}$ & $1.8 \pm 0.1$ & $55.3 \pm 10.3^{\mathrm{b}}$ \\
\hline$\%$ of control & 91.2 & 63.9 & 70.5 & 100.0 & 61.8 \\
\hline \multicolumn{6}{|c|}{ Pyruvate as a substrate } \\
\hline Control & $3.4 \pm 0.6$ & $16.2 \pm 2.8$ & $4.8 \pm 0.1$ & $2.7 \pm 0.2$ & $17.3 \pm 2.8$ \\
\hline DBP-treated & $2.8 \pm 1.1$ & $8.8 \pm 2.0^{\mathrm{b}}$ & $3.1 \pm 0.1^{\mathrm{b}}$ & $2.7 \pm 0.2$ & $9.1 \pm 1.9^{\mathrm{b}}$ \\
\hline$\%$ of control & 83.9 & 54.3 & 64.6 & 100.0 & 52.6 \\
\hline \multicolumn{6}{|c|}{ Glutamate as a substrate } \\
\hline Control & $10.1 \pm 5.7$ & $47.5 \pm 12.6$ & $4.7 \pm 0.6$ & $2.8 \pm 0.2$ & $51.3 \pm 10.9$ \\
\hline DBP-treated & $11.3 \pm 6.4$ & $42.6 \pm 12.6$ & $3.8 \pm 0.3$ & $2.7 \pm 0.2$ & $42.6 \pm 9.4$ \\
\hline$\%$ of control & 111.9 & 89.7 & 80.9 & 96.4 & 83.0 \\
\hline
\end{tabular}

Each value represents the mean $\pm \mathrm{SE}$ of five animals. a : Expressed as nanomole $\mathrm{O}_{2}$ per minute per milligram protein. b, $\mathrm{c}$ : Significantly different from control (b: $p<0.01, \mathrm{c}: p<0.05)$.

Table 3 Effect of DBP in vitro on the respiration of liver mitochondria of normal rats. Succinate was used as a respiratory substrate. The other conditions were as for Table 2.

\begin{tabular}{cccccc}
\hline & \multicolumn{2}{c}{$\mathrm{O}_{2}$ uptake $^{\mathrm{a}}$} & & \multicolumn{2}{c}{$\mathrm{O}_{2}$ uptake $^{\mathrm{a}}$} \\
\cline { 2 - 4 } $\mathrm{DBP}(\mu \mathrm{M})$ & State 4 & State 3 & RCI & P : O & DNP-induced \\
\hline 0 & $15.2 \pm 0.6$ & $73.0 \pm 10.6$ & $4.8 \pm 0.5$ & $1.9 \pm 0.1$ & $71.0 \pm 11.6$ \\
50 & $16.4 \pm 0.0$ & $63.3 \pm 0.1$ & $3.9 \pm 0.6$ & $1.9 \pm 0.1$ & $64.8 \pm 6.7$ \\
100 & $26.0 \pm 1.0$ & $51.2 \pm 1.0$ & $2.0 \pm 0.0$ & $1.2 \pm 0.2$ & $49.5 \pm 2.3$ \\
150 & $36.7 \pm 2.1$ & $36.7 \pm 2.1$ & $1.0 \pm 0.0$ & - & $36.7 \pm 2.1$ \\
200 & $31.8 \pm 4.4$ & $31.8 \pm 4.4$ & $1.0 \pm 0.0$ & - & $31.8 \pm 4.4$ \\
300 & $20.4 \pm 0.9$ & $20.4 \pm 0.9$ & $1.0 \pm 0.0$ & - & $20.4 \pm 0.9$ \\
400 & $16.2 \pm 3.5$ & $16.2 \pm 3.5$ & $1.0 \pm 0.0$ & - & $16.2 \pm 0.9$ \\
\hline
\end{tabular}

Each value represents the mean $\pm S D$. a : Expressed as nanomole $\mathrm{O}_{2}$ per minute per milligram protein.

\section{Dehydrogenase activity in liver mitochondria}

Dehydrogenases activities in DBP-treated rat liver mitochondria were shown in Table 4. Glutamate dehydrogenase activity was decreased by $73 \%$ of the control value but this was not significant. Succinate and pyruvate dehydrogenase activities were significantly decreased by $59 \%$ and $38 \%$ of the control values, respectively. These inhibitory effects were also observed in pair feeding rats, though they were somewhat weak compared with rats fed ad libitum (Table 4). The inhibitory potency for dehydrogenase activity was very close to that for respiratory activity shown in Table 2. Thus, these data clearly show that the respiratory inhibition by DBP administration was mainly caused by the inhibitory effect on dehydrogenase activity rather than on the other respiratory pathways.

The results obtained in vitro are shown in Table 5. Succinate dehydrogenase activity was more greatly inhibited as DBP concentration increased, and 100-200 $\mu \mathrm{M}$ DBP provided inhibition similar to that see in vivo. ATP synthesis in submitochondrial particles (+ succinate), which are inside-out relative to the membranes of mitochondria ${ }^{19)}$, was also reduced by $41 \%$ of the control when $400 \mu \mathrm{M}$ DBP was 
added (Table 6 ). The degree of reduction was very close to that (35.1\%) of dehydrogenase activity at the same DBP concentration, as shown in Table 5.

\section{DISCUSSION}

In the present study, DBP-treated rats revealed depressed growth, liver enlargement (increased relative weight) and testicular atrophy, effects

Table 4 Dehydrogenase activity in liver mitochondria of DBP-treated rats. Conditions were as described under the Materials and Methods.

\begin{tabular}{lccc}
\hline & \multicolumn{3}{c}{ Actitivty of dehydrogenase ${ }^{\mathrm{a}}$} \\
\cline { 2 - 4 } & Succinate & Pyruvate & Glutamate \\
\hline Ad lib. & & & \\
Control & $0.41 \pm 0.02$ & $0.08 \pm 0.01$ & $0.15 \pm 0.04$ \\
DBP-treated & $0.24 \pm 0.02^{\mathrm{b}}$ & $0.03 \pm 0.00^{\mathrm{b}}$ & $0.11 \pm 0.02$ \\
\% of control & 58.5 & 37.5 & 73.3 \\
Pair feeding & & & \\
Control & $0.42 \pm 0.04$ & $0.12 \pm 0.00$ & $0.17 \pm 0.01$ \\
DBP-treated & $0.28 \pm 0.06^{\mathrm{b}}$ & $0.07 \pm 0.01^{\mathrm{b}}$ & $0.14 \pm 0.02$ \\
\% of control & 66.7 & 58.3 & 82.4 \\
\hline
\end{tabular}

Each value represents the mean $\pm \mathrm{SE}$ of five animals. a : Expressed as micromole reduced potassium ferricyanide per minute per milligram protein. $\mathrm{b}$ : Significantly different from control $(p<0.01)$.

Table 5 Effect of DBP in vitro on the succinate dehydrogenase activity in liver mitochondria of normal rats. Conditions were as described under the Materials and Methods.

\begin{tabular}{rcc}
\hline $\operatorname{DBP}(\mu \mathrm{M})$ & Activity $^{\mathrm{a}}$ & $\%$ \\
\hline 0 & $0.77 \pm 0.04$ & 100 \\
100 & $0.54 \pm 0.03$ & 70.1 \\
200 & $0.44 \pm 0.03$ & 57.1 \\
400 & $0.27 \pm 0.02$ & 35.1 \\
1000 & $0.15 \pm 0.02$ & 19.5 \\
\hline
\end{tabular}

Each value represents the mean \pm SD. a : Expressed as micromole reduced potassium ferricyanide per minute per milligram protein.

Table 6 Effect of DBP on ATP formation in submitochondrial particles of normal rat liver. Conditions were as described under the Materials and Methods.

\begin{tabular}{ccc}
\hline $\operatorname{DBP}(\mu \mathrm{M})$ & ATP formation & $\%$ \\
\hline 0 & $43.5 \pm 2.1$ & 100 \\
400 & $18.0 \pm 1.4$ & 41 \\
\hline
\end{tabular}

Each value represents the mean \pm SD. a : Expressed as nanomole ATP per minute per milligram protein. common to previous reports ${ }^{4,5,20 ~ 23)}$. These animals also evidenced depressed respiration in liver mitochondria when succinate or pyruvate was used as a substrate. State 4 respiration was not, however, altered significantly, suggesting the absence of any effect on the coupling between respiration and phosphorylation at the given dose. The main inhibitory effects were seen in state 3 and DNPinduced respiration. However, the $\mathrm{P} / \mathrm{O}$ ratios of DBP-treated and control mitochondria were almost the same. Moreover, the inhibitory effect on respiration was the same as that of succinate and pyruvate dehydrogenases activities.

Therefore, these findings clearly show that the respiratory inhibition by DBP administration was mainly caused by the inhibitory effect on succinate and pyruvate dehydrogenases rather than on the other respiratory pathways or the energy transduction system in mitochondria.

ATP synthesis in submitochondrial particles (+ succinate), which are inside-out relative to the membranes of mitochondria ${ }^{19)}$, was decreased by $41 \%$ of the control value at a concentration of 400 $\mu \mathrm{M} \mathrm{DBP}$, which was very close to the inhibition (35.1\%) of succinate dehydrogenase activity in mitochondria at the same concentration of DBP. These results clearly show that DBP can be easily taken up into the matrix of mitochondria and that it acts directly on succinate dehydrogenase without altering the transport system for succinate.

Potent effects of DBP on liver mitochondrial function observed in the treated rats of this study were reproducible in vitro. This finding suggests that intact DBP, when elevated in the liver, contributes considerably to the development of adverse effects at least on the liver, especially since the existence of intact DBP in the liver a short time after an oral dose of DBP, though presumably in small amounts, has been suggested by analysis of metabolites in urine ${ }^{24)}$ and in the bile ${ }^{25)}$.

Since no definite information is available on the extent to which DBP plasticizer migrates from plastic materials into food or blood, it should be noticed that the significance of the present findings 
in relation to human exposure remains to be determined.

\section{SUMMARY}

Rats fed a diet containing $5 \%$ dibutyl phthalate (DBP) for 35 to 45 days revealed growth depression, liver enlargement and testicular atrophy. These effects were accompanied by inhibited respiration in liver mitochondria. This inhibition was caused by the decrease of succinate and pyruvate dehydrogenases activities rather than by the inhibition in the other respiratory redox components, in the coupling process or in the energy-transfer process. Such inhibitory effect was also observed in vitro, where nealy the same inhibitory potency as that found in vivo, occurred at a concentration less than $100 \mu \mathrm{M}$ DBP for the respiration and $150 \mu \mathrm{M}$ DBP for the dehydrogenase activities. The present study also showed that DBP can be easily taken up into the matrix of mitochondria and that it directly affects succinate dehydrogenase without altering the transport system for succinate.

\section{REFERENCES}

1) Thomas, J.A., Darby, T.D., Wallin, R.F., Garvin, P.J. and Martis, L. : A review of the biological effects of di(2-ethylhexyl) phthalate, Toxicol. Appl. Pharmacol., 45, 1-27 (1978).

2) Giam, C.S., Chan, H.S., Neff, G.S. and Atlas, E.C.: Phthalate ester plasticizers: A new class of marine pollutants, Science, 199, 419-421 (1978).

3) Kluwe, W.M., Haseman, J.K., Douglas, J.F. and Huff, J.E. : The carcinogenicity of dietary di (2-ethylhexyl) phthalate (DEHP) in Fischer 344 rats and B6C3F mice, J. Toxicol. Envirom. Health, 10, 797-815 (1982).

4) Lake, B.G., Gangolli, S.D., Grasso, P. and Lloyd, A.G. : Studies on the hepatic effects of orally administered di-(2-ethylhexyl) phthalate in the rat, Toxicol. Appl. Pharmacol., 32, 355-367 (1975).

5) Lake, B.G., Brantom, P.G., Gangolli, S.D., Butterworth, K.R. and Grasso, P.: Studies on the effects of orally administered di-(2-ethylhexyl) phthalate in the ferret, Toxicology, 6, 341-356 (1976).

6) Lake, B.G., Gray, T.J.B., Foster, J.R., Stubberfield, C.R. and Gangolli, S.D. : Comparative studies on di(2-ethylhexyl) phthalate-induced hepatic peroxisome proliferation in the rat and hamster, Toxicol. Appl. Pharmacol., 72, 46-60 (1984).

7) Srivastava, S.P., Agarwah, D.H. and Seth, P.K. : Effect of di-2-ethylhexyl phthalate on the activity of succinic dehydrogenase and adenosine triphosphatase of some vital organs of rat, Toxicology, 7, 163-168 (1977).

8) Mann, A.H., Price, S.C., Mitchell, F.E., Grasso, P., Hinton, R.H. and Bridges, J.W.: Comparison of the short-term effects of di (2-ethylhexyl) phthalate, di (n-hexyl) phthalate, and di (n-octyl) phthalate in rats, Toxicol. Appl. Pharmacol., 77, 116-132 (1985).

9) Ohyama, T.: Effects of phthalate esters on the respiration of rat liver mitochondria, J. Biochem., 79, 153-158 (1976).

10) Takahashi, T.: Biochemical studies on phthalic esters-II. Effects of phthalic esters on mitochondrial respiration of rat liver, Biochem. Pharmacol,, 26, 19-24 (1977).

11) Inouye, B., Ogino, Y., Ishida, T., Ogata, M. and Utsumi, K.: Effects of phthalate esters on mitochondrial oxidative phosphorylation in the rat, Toxicol. Appl. Pharmacol., 43, 189-198 (1978).

12) Hogeboom, G.H.: Fractionation of cell components of animal tissues, Methods in Enzymology (Colowick, S. P. and Kapla, N.O. eds.), Vol. 1, p. 16-18, Academic Press, New York (1955).

13) Higuti, T., Mizuno, S. and Muraoka, S. : Stepwise reduction of cytochromes b-562, b-566, and b-558, in rat liver mitochondria, Biochim. Biophys. Acta, 396, 36-47 (1975).

14) Higuti, T., Sato, M., Mizuno, S., Yokota, M., Sugiyama, Y., Nishitani, Y., Sekiya, M. and Tani, I. : Energization of mitochondrial inner membranes caused by L-malate, Biochim. Biophys. Acta, 449, 10-20 (1976).

15) Chance, B., Azzi, A., Lee, C.P. and Mela, L.: in Structure and Function of Mitochondria (Ernster, L. and Drahota, Z. eds.), p. 233-239, Academic Press, New York (1969).

16) Gulber, C.J. : Studies of the physiological functions of thiamine, J. Biol. Chem., 236, 3112-3120 (1961).

17) Hansen, M. and Smith, A.L.: Studies on the mechanism of oxidative phosphorylation VII, Preparation of a submitochondrial particle $\left(\mathrm{ETP}_{\mathrm{H}}\right)$ which is capable of fully coupled oxidative phosphorylation, Biochim. Biophys. Acta, 81, 214-222 (1964).

18) Higuti, T., Arakaki, N., Niimi, S., Nakasima, S., Saito, R., Tani, I. and Ota, F.: Anisotropic inhibition of energy transduction in oxidative phosphorylation in rat liver mitochondria by tetraphenylarsonium, J. Biol. Chem., 255, 7631-7636 (1980).

19) Higuti, T. : Conformational coupling in $\mathrm{H}^{+}$-pumps and ATP synthesis - its analysis with anisotropic inhibitors 
of energy transduction in oxidative phosphorylation, Mol. Cell. Biochem., 61, 37-61 (1984).

20) Nikonorow, M., Mazur, H. and Piekacz, H. : Effect of orally administered plasticizers and polyvinyl chloride stabilizers in the rat, Toxicol. Appl. Pharmacol., 26, 253-259 (1973).

21) Gray, T.J.B., Butterworth, K.R., Gaunt, I.F., Grasso, P. and Gangolli, S.D. : Short-term toxicity study of di(2-ethylhexyl) phthalate in rats, Fd. Cosmet. Toxicol., 15, 389-399 (1977).

22) Gray, T.J.B. and Butterworth, K.R.: Testicular atrophy produced by phthalate esters, Arch. Toxicol. Suppl., 4, 452-455 (1980).

23) Mangham, B.A., Foster, J.R. and Lake, B.G.: Comparison of the hepatic and testicular effects of orally administered di (2-ethylhexyl) phthalate and dialkyl 79 phthalate in the rat, Toxicol. Appl. Pharmacol., 61, 205-214 (1981).

24) Albro, P.W. and Moore, B.: Identification of the metabolites of simple phthalate diesters in rat urine, J. Chromatography, 94, 209-218 (1974).

25) Tanaka, A., Matsumoto, A. and Yamaha, T.: Biochemical studies on phthalic esters. III. Metabolism of dibutyl phthalate (DBP) in animals, Toxicol., 9, 109-123 (1978).

26) Hagihara, B.: Techniques for the application of polarography to mitochondrial respiration, Biochim. Biophys. Acta, 46, 134-142 (1961).

\title{
フタル酸ジブチル経口投与のラット肝ミトコンドリアに及ぼす影響
}

\author{
徳島大学医学部衛生学教室 \\ 村 上 憲 司・西山敬 太 郎 \\ 徳島大学薬学部微生物薬品化学教室
}

樋口富彦

ラットに $5 \%$ フタル酸ジブチル (DBP) 含有粉末飼料を 35 45日間与えた結果, 成長抑制, 肝肥大, 精巣萎縮が認め られた。又, 同時に肝ミトコンドリアの呼吸抑制が認められた。この呼吸抑制はコハク酸およびピルビン酸脱水素酵素 の活性低下によるものであった。

このような DBP のミトコンドリアに及ぽす影響は in vitro でも確認された。即ち in vivo で観察された呼吸活性の低

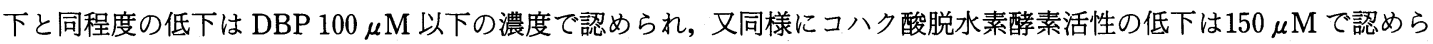
れた。

又, 亜ミトコンドリア粒子を用いた実験結果から，DBP は容易にミトコンドリア内に入り，コハク酸の膜透過には変 化を与えず，コハク酸脱水素酵素活性に直接作用することが示された。

Key words: Dibutyl phthalate, Toxicity, Rat liver, Mitochondrial respiration, Dehydrogenase activity

フタル酸ジブチル，毒性，ラット肝，ミトコンドリア呼吸，脱水素酵素活性 